\title{
PENGARUH PROCESS-ORIENTED GUIDED-INQUIRY LEARNING (POGIL) TERHADAP KEMAMPUAN PROBLEM SOLVING SISWA
}

\author{
Ivan Ashif Ardhana ${ }^{1}$ \\ ${ }^{1}$ IAIN Tulungagung, Kementerian Agama, Tulungagung \\ 1ivanashif@gmail.com
}

https://doi.org/10.36052/andragogi.v8i1.133

Diterima: 24 April 2020 | Disetujui: 8 Juni 2020 | Dipublikasikan: 30 Juni 2020

\begin{abstract}
Abstrak
Penelitian ini bertujuan mengetahui perbedaan pengaruh pembelajaran Process-Oriented Guided-Inquiry Learning (POGIL) dan verifikasi terhadap kemampuan problem solving siswa SMA kelas XI program IPA pada topik asam-basa. Desain penelitian yang digunakan adalah eksperimen semu (quasi experimental). Pengujian hipotesis dilakukan menggunakan uji-t dengan taraf signifikansi 5\% menggunakan bantuan program SPSS 21 for windows. Hasil penelitian menunjukkan bahwa (1) terdapat perbedaan kemampuan problem solving secara signifikan antara siswa yang dibelajarkan menggunakan pendekatan POGIL dan verifikasi; dan (2) siswa yang dibelajarkan menggunakan pendekatan POGIL mampu memberikan pola jawaban yang lebih baik daripada siswa yang dibelajarkan menggunakan pendekatan verifikasi. Berdasarkan hasil penelitian, POGIL layak dipromosikan sebagai pendekatan pembelajaran yang cocok untuk mengembangkan kemampuan problem solving siswa pada topik asam-basa. Implikasi terhadap penelitian serupa selanjutnya adalah perlunya eksplorasi kemampuan problem solving pada topik kimia kontekstual lainnya seperti laju reaksi, kesetimbangan, dan sifat koligatif. Eksplorasi keterlibatan metakognisi dalam POGIL juga merupakan implikasi lain yang dapat dikaji lebih mendalam.
\end{abstract}

Kata Kunci: problem solving, POGIL, verifikasi, asam-basa

\begin{abstract}
[THE EFFECT OF PROCESS-ORIENTED GUIDED-INQUIRY LEARNING (POGIL) TOWARD STUDENTS' PROBLEM SOLVING SKILLS]. The aim of this research is to investigate the different impacts of Process-Oriented GuidedInquiry Learning (POGIL) and verification as a learning approach at senior high school students' problem solving ability grade XI program IPA on acid-base topic. The research design used was quasi experimental. Hypothesis testing uses a t-test with 5\% significance utilizing SPSS 21 program for windows. Results show that (1) there is a significant difference in students' problem solving ability that is taught by POGIL approach and verification, and (2) students that are taught by POGIL approach give better answer's pattern than students that are taught by verification approach. According to the research result, POGIL could be well promoted learning model to developing problem solving skill on acid-base topics. This result does imply to the next similar research that appropriate exploration of problem solving ability on another contextual chemistry topic such as rate of reaction, chemical equilibrium, and colligative properties. Exploration about metacognition involvement on POGIL also the other implication of this research result that can be deeply analyzed.
\end{abstract}

Keywords: problem solving, POGIL, verification, Acid-Base 


\section{PENDAHULUAN}

$S$ alah satu topik kimia yang diajarkan kepada siswa SMA/MA adalah asambasa. Topik ini tercantum pada kompetensi dasar 3.10 yaitu "Menganalisis sifat larutan berdasarkan konsep asam-basa dan/atau pH larutan" dan kompetensi dasar 4.10 yaitu "Mengajukan ide/gagasan tentang penggunaan indikator yang tepat untuk menentukan keasaman Asam/Basa atau titrasi Asam/Basa". Topik asam-basa penting dipahami secara tepat karena memiliki kebermanfaatan yang luas, bersifat kontekstual aplikatif, dan menjadi bagian integral kajian keilmuan multi bidang seperti aktivitas biokimia, proses industri, permasalahan lingkungan, dan perkembangan teknologi (Furió-Más et al., 2007).

Ciri-ciri topik asam-basa adalah berkaitan dengan aspek sosial masyarakat dan bersifat kontekstual. Hal tersebut didasari bahwa topik asam-basa disajikan oleh sejumlah textbook dari sudut pandang relevansi dengan kehidupan personal siswa, masyarakat, dan kontekstual aplikatif (De Vos \& Pilot, 2001). Aplikasi konteks dunia nyata (real-world context) tersebut didasari ide pedagogis bahwa siswa belajar lebih baik ketika mereka dapat melihat relevansi topik yang dipelajari. Penekanan konteks tersebut bertujuan membentuk pemahaman siswa tentang pentingnya kimia, membentuk masyarakat yang bertanggung jawab terhadap lingkungan, dan peduli terhadap kesehatan.

Berdasarkan ciri-ciri di atas, maka topik asam-basa perlu dipahami dengan baik oleh siswa. Namun, hasil-hasil investigasi pemahaman topik asam-basa menunjukkan bahwa siswa masih mengalami kesulitan dan miskonsepsi. Sejumlah kesulitan yang dialami siswa adalah tidak mampu mendefinisikan secara akurat istilah $\mathrm{pH}$, netralisasi dan kekuatan asam (Sheppard, 2006). Pada penelitian tersebut, ditemukan pula kesulitan siswa dalam mengaitkan konsep kimia dengan permasalahan aktual. Kesulitan tersebut diduga berasal dari kurangnya pemahaman siswa pada konsep-konsep dasar kimia seperti perubahan kimia dan sifat materi. Akibatnya, siswa kesulitan menerapkan pemahaman jika menemui suatu problem baru.

Kesulitan siswa pada topik asam-basa pada penelitian lain adalah tidak memahami perbedaan disosiasi dan ionisasi (Furió-Más et al., 2007). Pada penelitian tersebut, sebagian besar siswa tidak mampu membedakan antara senyawa ion dan molekul polar dari partikel penyusunnya. Siswa juga tidak mampu membedakan proses disosiasi saat senyawa ionik dilarutkan ke dalam air dengan proses ionisasi saat molekul polar dilarutkan ke dalam air membentuk ion-ion. Hal ini disebabkan oleh kesulitan siswa mengaplikasikan pengetahuan teoritik untuk menentukan apakah proses disosiasi benar-benar terjadi pada sebuah problem terkait.

Pada aspek sikap, siswa tidak percaya diri dalam menuliskan rumus molekul (Orgill \& Sutherland, 2008). Hal ini berdampak pada kesulitan siswa dalam memahami konsepkonsep larutan seperti larutan asam-basa dan larutan penyangga. Penelitian lain melaporkan bahwa siswa tidak mampu mengaitkan konsepkonsep dengan permasalahan kehidupan seharihari seputar topik asam-basa (Çalik \& Ayas, 2005). Siswa merasa tidak menemui kecocokan antara pengetahuan yang diajarkan di kelas dengan permasalahan yang ditemui dalam kehidupan sehari-hari. Adapun miskonsepsi pada topik asam-basa di antaranya adalah kepolaran ikatan adalah satu-satunya faktor yang mempengaruhi kekuatan asam (Tümay, 2016); larutan $\mathrm{HCl} 10^{-8} \mathrm{M}$ memiliki $\mathrm{pH} 8$ dan netralisasi selalu menghasilkan larutan netral dengan pH 7 (Pinarbasi, 2007). Hasil-hasil analisis penelitian yang telah dilaporkan di atas menunjukkan bahwa masalah utama konsepkonsep pada topik asam-basa dianggap sulit oleh siswa adalah kurangnya kemampuan siswa mengaplikasikan pengetahuan ke dalam permasalahan baru.

Kesulitan siswa dalam memahami topik asam-basa dapat disebabkan oleh ketidakmampuan siswa melakukan transisi pemahaman antara representasi makroskopik, submikroskopik, dan simbolik sehingga berpotensi menyebabkan pemahaman siswa menjadi tidak tepat dan bahkan cenderung menimbulkan miskonsepsi (Furió-Más et al., 2007; Thomas \& Anderson, 2014). Salah satu 
kesulitan siswa dalam mempelajari kimia adalah tidak mampu menginterelasikan pemahaman dari satu level representasi menuju level representasi lainnya (Gabel, 1999). Kesulitan tersebut diikuti ketidakmampuan siswa menggunakan pengetahuan yang telah didapat ke dalam informasi atau permasalahan baru yang diberikan (Nakhleh, 1994).

Kemampuan menggunakan pengetahuan yang telah didapat ke dalam informasi atau permasalahan baru merupakan suatu proses pemecahan masalah (problem solving). Pemahaman terhadap topik asam-basa diperlukan kemampuan problem solving. Problem solving merupakan aktivitas mental yang dialami individu untuk mendapatkan jawaban terbaik dari suatu masalah (Wood, 2006). Aktivitas mental tersebut melibatkan sejumlah proses kognitif yakni perolehan kembali pengetahuan dari memori deklaratif dan prosedural, pemilihan prosedur alternatif dalam mencari jawaban, dan validasi atau bahkan sangkalan terhadap jawaban yang telah didapat. Gagne dalam teorinya menyatakan bahwa pembelajaran menjadi bermakna apabila siswa dihadapkan pada suatu problem baru dan menggunakan pengetahuannya untuk menyelesaikan problem tersebut.

Problem solving versi Polya dianggap paling efektif dengan melibatkan empat langkah yaitu (1) memahami masalah (understanding the problem); (2) membuat perencanaan (devising a plan); (3) melaksanakan perencanaan (carrying out the plan); dan (4) mengevaluasi pelaksanaan (looking back) (Bilgin, 2006; Noh et al., 2005). Untuk melaksanakan langkah-langkah tersebut, dibutuhkan sejumlah kemampuan yaitu (1) dasar pengetahuan terhadap konten problem; (2) kemampuan berpikir analisis (mengklasifikasikan, memeriksa konsistensi, memberikan alasan, dan mengidentifikasi hubungan), (3) kemampuan menggenerelasikan, menyederhanakan, dan memperluas perspektif; (4) sikap positif seperti motivasi, kreatif, sabar, dan pantang menyerah; (5) kemampuan menghadapi keambiguan, ketakutan, dan kecemasan; (6) kemampuan interpersonal, berkelompok, dan berkomunikasi; (7) kemampuan untuk mengidentifikasi, menempatkan, mendapat, dan mengevaluasi informasi yang hilang; (8) serta kesadaran terhadap bagaimana cara berpikir dan memproses informasi (Woods, 1987). Problem solving kimia dapat dikembangkan dengan memberikan permasalahan baru yang berkaitan langsung dengan kehidupan sehari-hari, isu sosial sains, atau permasalahan lingkungan.

Problem solving pada topik asam-basa diperlukan siswa untuk menjawab sejumlah permasalahan kontekstual kontemporer seperti pengasaman lautan, hujan asam, polusi udara, atau pengeroposan gigi. Sebagai contoh, siswa yang diberikan permasalahan lingkungan mengenai hujan asam akan menstimulasi dirinya merencanakan penyelesaian masalah dengan memanggil kembali ingatan tentang konsep-konsep asam-basa yang diperlukan untuk menyelesaikan masalah tersebut. Siswa kemudian memantau langkah-langkah yang benar dalam melakukan perhitungan $\mathrm{pH}$ pada lingkungan terdampak hujan asam. Siswa juga akan melakukan koreksi kebenaran informasi hujan asam dan penyelesaian perhitungan $\mathrm{pH}$ yang telah dilakukan. Upaya merencanakan (planning), memantau (monitoring), dan mengoreksi (evaluating) merupakan indikator aktivitas metakognisi yang terlibat dalam aktivitas problem solving (Moshman, 2018). Kebutuhan topik asam-basa tersebut diperlukan pembelajaran yang dapat mengembangkan kemampuan problem solving.

Sejumlah penelitian menunjukkan bahwa keterlibatan aktivitas problem solving dalam pembelajaran dapat meningkatkan kemampuan pemecahan masalah (Bilgin, 2006; Broman \& Parchmann, 2014; Noh et al., 2005). Problem solving merupakan topik sentral pada konteks pendidikan modern dan meletakkan kimia pada kondisi yang lebih realistis dan kontekstual serta menunjukkan pada masyarakat bahwa kimia membutuhkan pemikiran kritis dan pengambilan resiko (Greiff, 2012; Wood, 2006). Dengan demikian, agar pembelajaran memberikan capaian yang positif dari segi berpikir dan sikap ilmiah, dibutuhkan pembelajaran yang optimal dalam mengembangkan kemampuan problem solving.

Pembelajaran verifikasi masih banyak digunakan oleh para guru di sekolah-sekolah dengan alasan bahwa siswa telah mampu 
meraih nilai yang bagus dan lebih efisien waktu. Verifikasi merupakan jenis pembelajaran tradisional behavioristik. Pembelajaran tradisional didominasi oleh transfer pengetahuan, interaksi guru-siswa yang minimal, dan tidak terjadi proses kooperatif antar siswa (Moog \& Spencer, 2008). Transfer pengetahuan dilakukan guru dengan berceramah, menjelaskan konsep, menunjukkan analogi, memberikan jawaban soal, dan mendemonstrasikan langkah demi langkah bagaimana menyelesaikan sejumlah soal latihan. Siswa dalam sudut pandang behavioristik merupakan sebuah objek yang dimanipulasi oleh guru, diberikan stimulus berupa pengetahuan, dan dikondisikan untuk melakukan respon dengan pemberian reward sebagai reinforcement (Dudley Herron \& Nurrenbern, 1999). Pembelajaran tradisional verifikasi dimulai dengan pemberian konsep dan kemudian diberikan data sebagai bukti kebenaran konsep tersebut (Pavelich \& Abraham, 1979). Pemberian data pembuktian dapat dilakukan melalui aktivitas laboratorium, observasi video, demonstrasi, atau latihan soal.

Inkuiri merupakan salah satu pendekatan pembelajaran konstruktivistik yang dapat mengakuisisi kebutuhan konstruk konsep dan proses mental siswa. Salah satu versi inkuiri terbimbing yang telah dikembangkan oleh para pakar pembelajaran adalah Process-Oriented Guided-Inquiry Learning (POGIL). POGIL dikembangkan oleh (Hanson, 2005) dengan memanfaatkan learning cycle (daur belajar) sebagai panduan pelaksanaan inkuiri terbimbing sehingga memiliki tahap-tahap yang fleksibel untuk memfasilitasi siswa dalam membangun konsep. Tahap-tahap POGIL adalah orientasi, eksplorasi, pembentukan konsep, aplikasi, dan penutup yang dilaksanakan oleh siswa dalam kelompok-kelompok kecil.

Process-Oriented Guided-Inquiry Learning (POGIL) merupakan salah satu versi pembelajaran berparadigma konstruktivisme dan student-centered yang efektif melibatkan kemampuan berpikir siswa dalam membentuk pengetahuan. POGIL berlandaskan teori konstruktivisme sosial (social constructivism) dimana pengetahuan dibangun oleh pebelajar sendiri melalui interaksi sosial kooperatif (Eberlein et al., 2008). POGIL dibangun berlandasakan filosofi bahwa siswa belajar dengan efektif apabila secara aktif terlibat dalam aktivitas kelas dan laboratorium; menarik kesimpulan dengan menganalisa data, model, atau contoh; mendiskusikan gagasan; bekerja sama dalam kelompok; memecahkan masalah; merefleksi hasil belajar; meningkatkan perfoma; dan berinteraksi dengan guru sebagai fasilitator (Karadan \& Hameed, 2016). POGIL juga bertujuan mengembangkan penguasaan konten dan kemampuan proses dengan menyediakan akses pengetahuan awal, mengolah informasi, berpikir kritis, problem solving, komunikasi oral dan tertulis, bekerja sama, manajemen, refleksi, dan penilaian (Hanson, 2005; Karadan \& Hameed, 2016; Moog \& Spencer, 2008).

POGIL dapat mengembangkan kemampuan problem solving terutama pada tahap aplikasi (Eberlein et al., 2008; Hanson, 2005; Moog \& Spencer, 2008), sehingga POGIL memiliki aktivitas pembelajaran yang lebih kontekstual. Gagasan ini didukung oleh sejumlah peneliti bahwa format inkuiri terbimbing dapat mengakomodasi kemampuan pemecahan masalah (Abd-El-Khalick et al., 2004). Pertanyaan-pertanyaan pembimbing pada tiap tahap merupakan sebuah problem bagi siswa dimana solving terhadapnya adalah sebuah output pemahaman. Tahap aplikasi paling berpotensi dapat mengembangkan kemampuan problem solving apabila diberikan soal atau permasalahan baru untuk menginternalisasi konsep yang telah dikonstruk sebelumnya. Upaya mengaplikasikan konsep yang telah terbentuk ke dalam permasalahan baru merupakan proses problem solving yang dimunculkan.

Kontekstualisasi konten menjadi keunggulan lain dari POGIL dibandingkan inkuiri terbimbing versi lain yaitu dapat mengakomodasi karakter kontekstual dari sebuah topik ajar. Topik asam-basa merupakan salah satu topik kimia berkarakter kontekstual yang cocok diajarkan menggunakan POGIL (Yuliastini et al., 2018). Apabila kemampuan problem solving dikembangkan pada pembelajaran, maka siswa dapat memberikan solving kepada problem yang lebih kontekstual secara lebih optimal. Berdasarkan uraian di atas maka perlu dilakukan investigasi dampak 
pembelajaran POGIL dan verifikasi terhadap kemampuan problem solving siswa pada topikaAsam-basa.

\section{METODE PENELITIAN}

Penelitian ini menggunakan rancangan penelitian eksperimental semu (quasy experimental design). Rancangan penelitian eksperimental semu digunakan untuk mengetahui dampak pembelajaran POGIL vs verifikasi terhadap kemampuan problem solving. Sejumlah variabel digunakan dalam penelitian ini. Variabel bebas yaitu jenis pembelajaran POGIL vs verifikasi. Variabel terikat yaitu kemampuan problem solving. Variabel kontrol yaitu guru, alokasi waktu belajar, dan topik ajar yang diadministrasikan dalam bentuk buku kerja. Adapun variabel lain yang dapat memiliki pengaruh adalah variabel intervening berupa pengalaman siswa. Rancangan penelitian ditunjukkan pada Tabel 1.

Tabel 1 Rancangan Penelitian

\begin{tabular}{lcc}
\hline Kelompok & Perlakuan & Posttest \\
\hline Eksperimen & $X_{1}$ & $0_{1}$ \\
\hline Kontrol & $X_{2}$ & $0_{1}$ \\
\hline
\end{tabular}

\section{Keterangan:}

$X_{1}$ : pembelajaran menggunakan POGIL

$X_{2}$ : pembelajaran menggunakan verifikasi

$\mathrm{O}_{1}$ : pemberian tes kemampuan problem solving

Penelitian ini dilakukan di SMA Negeri 8 Malang sebanyak 8 kali tatap muka pada bulan Juli-Agustus semester ganjil tahun ajaran 2017/2018. Populasi penelitian yaitu seluruh siswa kelas XI IPA SMA Negeri 8 Malang, sedangkan sampel penelitian adalah dua kelas yang dipilih dengan menggunakan teknik cluster random sampling. Cluster yang diambil adalah semluruh siswa kelas XI IPA dimana pada semester tersebut topik asam-basa diberikan. Dua kelas yang dipilih diambil berdasarkan uji kesamaan dua rata-rata hasil ujian yang tidak memiliki perbedaan signifikan pada topik kimia sebelumnya. Instrumen penelitian yang digunakan adalah instrumen perlakuan yang terdiri dari buku kerja beserta RPP dan instrumen pengukuran yang terdiri dari tes kemampuan problem solving. Penggunaan tes esai dinilai sangat tepat untuk menginvestigasi kemampuan problem solving siswa dalam berpikir dan aspek psikologis siswa dalam menjawab item soal. Validasi instrumen yang digunakan pada penelitian ini adalah validitas isi dan validasi konstruk/empiris. Validator yang dipilih adalah dua orang dosen kimia yang mengampu mata kuliah kimia dasar. Pada instrumen tes kemampuan problem solving, validator diminta untuk menilai keterwakilan konsep-konsep yang diteliti, kesesuaian dengan komponen kemampuan problem solving, dan kelayakan bahasa yang digunakan dalam tiap item soal.

Validitas empiris dilakukan melalui uji coba soal untuk mengetahui validitas dan reliabilitas tiap item soal. Validitas instrumen diukur menggunakan korelasi Pearson, sedangkan reliabilitas diukur menggunakan teknik Cronbach alpha. Teknik ini digunakan karena instrumen tes berupa soal esai. Pengumpulan data kemampuan problem solving dilakukan dengan teknik tes. Tes kemampuan problem solving diberikan setelah pembelajaran POGIL vs verifikasi pada topik asam-basa selesai dilaksanakan. Data yang dikumpulkan dianalisis secara kuantitatif menggunakan analisis statistik deskriptif dan inferensial. Analisis deskriptif digunakan untuk menjabarkan sebaran pola kemampuan problem solving siswa. Analisis statistik inferensial yang digunakan adalah analisis komparatif.

\section{TEMUAN DAN PEMBAHASAN}

\section{Temuan}

Kemampuan problem solving siswa pada topik asam-basa diukur menggunakan tes kemampuan problem solving sebanyak 4 artikel masalah. Tes berupa soal esai yang diberikan sebagai postes. Secara ringkas, hasil analisis deskriptif data skor kemampuan problem solving siswa kelas POGIL dan verifikasi disajikan pada Tabel 2.

Tabel 2 Ikhtisar Data Skor Kemampuan problem solving Siswa Kelas POGIL Dan Verifikasi

\begin{tabular}{lllll}
\hline \multirow{3}{*}{ Kelas } & \multicolumn{4}{l}{$\begin{array}{l}\text { Skor Kemampuan problem } \\
\text { solving }\end{array}$} \\
\cline { 2 - 5 } & $\mathbf{N}$ & $\mathbf{X}$ & $\begin{array}{l}\text { Skor } \\
\text { Max }\end{array}$ & SD \\
\hline Verifikasi & 28 & 64.25 & 85 & 5.86 \\
\hline POGIL & 27 & 69.26 & 85 & 6.04 \\
\hline
\end{tabular}


Berdasarkan data pada Tabel 2, rata-rata skor kemampuan problem solving siswa kelas POGIL adalah 69.26, lebih tinggi daripada rata-rata skor kemampuan problem solving siswa kelas verifikasi yaitu 64.25. Hasil tersebut menginterpretasikan bahwa pembelajaran POGIL memiliki dampak yang lebih signifikan daripada kelas verifikasi terhadap kemampuan problem solving siswa pada topik asam-basa.

Uji hipotesis dilakukan untuk mengetahui apakah terdapat perbedaan signifikan kemampuan problem solving siswa yang dibelajarkan menggunakan pendekatan POGIL dan verifikasi. Uji normalitas, uji homogenitas varian dan uji-t seluruhnya dilakukan dengan bantuan program statistik SPSS 21 for windows. Hasil uji normalitas, uji homogenitas varian, dan uji-t secara ringkas disajikan pada Tabel 3.

Tabel 3 Ikhtisar Hasil Uji Statistik Skor Tes Kemampuan Problem Solving

\begin{tabular}{|c|c|}
\hline Jenis Tes & Keputusan \\
\hline $\begin{array}{l}\text { Uji } \\
\text { Norma- } \\
\text { litas }\end{array}$ & $\begin{array}{l}0.508>\text { a }(0,005) \text { dan } 0.244>\text { a } \\
(0,005) \text {, maka } \mathrm{H}_{0} \text { diterima, data } \\
\text { kelas verifikasi dan POGIL } \\
\text { terdistribusi normal }\end{array}$ \\
\hline $\begin{array}{l}\text { Uji Homo- } \\
\text { genitas }\end{array}$ & $\begin{array}{l}0.177>\text { a }(0,005) \text {, maka } \mathrm{H}_{0} \\
\text { diterima, data kelas verifikasi dan } \\
\text { POGIL homogen }\end{array}$ \\
\hline Uji-t & $\begin{array}{l}\text { thitung }(4,565)>\mathrm{t}_{\text {tabel }}(2,000) \text { maka } \\
\mathrm{H}_{1} \text { diterima, terdapat perbedaan } \\
\text { kemampuan problem solving secara } \\
\text { signifikan antara kelas POGIL dan } \\
\text { verifikasi }\end{array}$ \\
\hline
\end{tabular}

Berdasarkan Tabel 3, data kelas kontrol dan eksperimen bersifat normal dan homogen. Dari nilai thitung yang diperoleh, dapat disimpulkan bahwa ada perbedaan kemampuan problem solving siswa pada topik asam-basa yang dibelajarkan menggunakan pendekatan POGIL dan verifikasi. Dalam hal ini, POGIL memberikan dampak yang lebih tinggi terhadap kemampuan problem solving. Hasil analisis data penelitian yang disajikan pada Tabel 2 dan 3 menunjukkan bahwa siswa yang dibelajarkan menggunakan pendekatan POGIL memiliki kemampuan problem solving yang lebih tinggi daripada siswa yang dibelajarkan menggunakan pendekatan verifikasi. Selanjutnya, hasil uji hipotesis menunjukkan bahwa ada perbedaan kemampuan problem solving siswa pada topik asam-basa yang dibelajarkan menggunakan pendekatan POGIL dan verifikasi. Berdasarkan hasil analisis tersebut, dapat disimpulkan bahwa pendekatan POGIL lebih efektif dalam mengembangkan kemampuan problem solving siswa pada topik aasam-basa dibandingkan pendekatan verifikasi.

Hasil penelitian dapat menjawab kesenjangan utama yakni literasi sains siswa Indonesia yang berdasarkan hasil PISA selalu berada di posisi bawah. Survei PISA terakhir pada tahun 2018 menunjukkan siswa Indonesia berada pada peringkat 74 dari 79 negara dengan kategori literasi rendah (OECD, 2019). Literasi merupakan kemampuan untuk menggunakan pengetahuan dan skills yang telah dikuasai ke dalam permasalahan dunia nyata. Secara lebih detail, kemampuan literasi sains diantaranya adalah mampu menggunakan pengetahuan saintifik, mampu mengusulkan pertanyaan (bertanya), dan mampu menarik kesimpulan dari fakta dalam rangka membantu membuat keputusan tentang kejadian di dunia dan perubahan dalam perspektif manusia (OECD, 2019). Salah satu literasi sains adalah kemampuan problem solving yang layak dilatihkan melalui model-model pembelajaran yang direkomendasikan seperti POGIL.

\section{Pembahasan}

Temuan penelitian ini dapat dikaji lebih lanjut dari dua hal, yaitu keterlibatan kemampuan transfer dan kemampuan proses. Pertama, siswa yang dibelajarkan menggunakan pendekatan POGIL memiliki kemampuan transfer yang lebih baik daripada siswa yang dibelajarkan menggunakan pendekatan verifikasi. Pada pembelajaran POGIL, siswa selalu dilibatkan dalam memahami problem dari serangkaian pertanyaan pembimbing dan menarik kesimpulan ilmiah dari jawaban-jawaban problem tersebut. Selain bersumber dari serangkaian pertanyaan pembimbing, kemampuan problem solving sangat kentara dilatihkan pada tahap aplikasi. Upaya siswa mengusulkan strategi terbaik mereka untuk menyelesaikan soal atau problem yang diberikan merupakan sumber eksplisit POGIL dapat melatihkan kemampuan problem 
solving. Siswa yang dibiasakan memahami dan menyelesaikan problem menghasilkan level pemahaman yang lebih mendalam terhadap suatu konstruk pengetahuan berkaitan dan lebih responsif terhadap permasalahan baru yang diberikan. Hasil penelitian sejalan dengan (Schraw et al., 2006) yang menyatakan bahwa strategi inkuiri memberikan kesempatan siswa secara verbal maupun tertulis mendeklarasikan strategi-strategi problem solving dalam menyelesaikan soal-soal yang diberikan.

Pada pembelajaran verifikasi, pemahaman dibangun siswa semata-mata dari penjelasan guru. Pembentukan konsep pada struktur pikiran siswa adalah melalui proses serah terima informasi yang berlangsung satu arah dan bersifat mutlak, sehingga membatasi siswa menginvestigasi konsep-konsep baru secara lebih mendalam. Pembelajaran searah tidak menyediakan porsi interaksi yang cukup antara siswa dengan konten pengetahuan. Hilangnya interaksi antara siswa dengan konten pengetahuan yang seharusnya difasilitasi guru melalui pertanyaan-pertanyaan pembimbing menyebabkan siswa tidak menemukan problemproblem konstruktif selama proses membangun konsep. Sistem seperti ini berdampak pada kurangnya kesempatan siswa dalam mengembangkan kemampuan problem solving. Pada kegiatan latihan soal atau problem solving, sekalipun soal dan problem yang diberikan sama dengan kelas POGIL, siswa kelas verifikasi kekurangan cara untuk memahami duduk persoalan dan menemukan strategistrategi taktis dalam menyelesaikan persoalan tersebut. Hal tersebut merupakan dampak dari pembelajaran verifikasi yang kurang melatihkan kemampuan siswa mengidentifikasi informasi dan strategi untuk menyelesaikan problem ilmiah.

Kedua, siswa yang dibelajarkan menggunakan pembelajaran POGIL memiliki kemampuan proses (process skill) yang lebih baik daripada siswa yang dibelajarkan menggunakan pendekatan verifikasi. Keunggulan kemampuan proses siswa kelas POGIL disebabkan oleh lebih banyaknya interaksi dengan sejumlah stimulasi intelektual dibandingkan dengan pembelajaran verifikasi. Kegiatan praktikum, pengamatan video, identifikasi pola visual, maupun analisis pertanyaan berpikir kritis merupakan stimulasi intelektual yang dijumpai siswa secara frekuentatif dan berulang. Serangkaian stimulasi intelektual yang dilakukan berulang memicu munculnya aktivitas-aktivitas kognitif dalam dinamika pikiran siswa. Aktivitas kognitif meliputi memanggil pengetahuan awal (prior knowledge), mengobservasi dan menginferensi data, mengkonstruksi konsep dari data eksplorasi, mengaplikasikan perolehan konsep pada soal-soal baru, serta menutupnya dengan refleksi kesuksesan belajar. Keajegan interaksi dengan stimulasi intelektual membuat siswa pada kelas POGIL mampu mengembangkan kemampuan prosesnya dengan lebih baik, sehingga berdampak pada lebih terampilnya siswa menerapkan perolehan konsep pada suatu problem baru.

Pada pembelajaran verifikasi, siswa memiliki keterbatasan partisipatif dalam membangun konsep. Meskipun pembelajaran ini dilanjutkan dengan pemberian stimulasi intelektual berupa kegiatan praktikum, pengamatan video ataupun analisis data, hal itu hanya sebagai bentuk pembuktian konten pengetahuan yang disampaikan guru di awal. Siswa diposisikan sebagai penerima informasi pasif yang hanya diperkenankan mendengar dan mencatat pengetahuan sebagai aktivitas kognitif yang dapat dipromosikan. Kegiatan seperti ini mencerminkan pembelajaran yang hanya berorientasi konten materi, mengabaikan kemampuan proses siswa dalam berpikir kritis dan visioner. Hal ini sejalan bahwa pada pembelajaran verifikasi, arah pembelajaran yaitu dari guru ke siswa, sehingga gagal dalam merefleksikan cara belajar dan mengajar yang konstruktivis serta mengurangi kesempatan siswa untuk mengembangkan kemampuan proses di dalamnya (Nada et al., 2018).

Ketiga, siswa yang dibelajarkan menggunakan POGIL menghasilkan produk kognisi yang lebih bermakna (meaningful) dibandingkan siswa yang dibelajarkan menggunakan pendekatan verifikasi. Pada pembelajaran POGIL, perolehan konsep didiferensiasi dari serangkaian aktivitas kognitif yang dilakukan secara langsung oleh siswa. Aktivitas kognitif yang dialami secara langsung menciptakan suatu kebermaknaan psikologis dalam struktur pikiran siswa. 
Pengalaman yang bermakna meninggalkan jejak-jejak intelektual yang terpatri kuat pada memori jangka panjang. Pengetahuan yang didapat melalui proses yang bermakna memberikan kemudahan dalam proses pemanggilan kembali dan dideklarasikan menjadi sebuah konten-konten pengetahuan yang lengkap dan informatif. Deklarasi pengetahuan dari pengalaman-pengalaman bermakna dapat secara tepat diaplikasikan pada problem-problem yang dijumpai.

Pada pembelajaran verifikasi, perolehan konsep siswa semata-mata hanya berasal dari aktivitas mendengarkan, mencatat, dan konfirmasi melalui kegiatan verifikasi. Aktivitas ini tidak memberikan kesempatan siswa menemukan makna belajar tentang mengapa suatu pengetahuan diperoleh melalui serangkaian proses saintifik tertentu. Siswa menjadi objek pasif tanpa mencoba menggali makna belajar yang dilakukan. Kurangnya kebermaknaan dalam belajar mengakibatkan jejak-jejak intelektual yang terekam dalam ruang kognisi siswa menjadi terbatas dan terfraksionasi. Rekaman-rekaman intelektual yang terfraksionasi membuat siswa kesulitan dalam memanggil kembali pengetahuan dan memungkinkan deklarasi pengetahuan menjadi tidak lengkap dan kurang informatif untuk diaplikasikan ke dalam problem-problem yang dijumpai

Keempat, siswa yang dibelajarkan menggunakan pendekatan POGIL memiliki retensi yang lebih baik daripada siswa yang dibelajarkan menggunakan pendekatan verifikasi. Retensi dapat terfasilitasi apabila siswa dilibatkan aktif dalam pembelajaran berbasis penemuan daripada melalui pembelajaran pasif yang mengutamakan transfer informasi dari ceramah dan buku teks. Pembelajaran berbasis penemuan seperti POGIL membentuk sebuah pengalaman empirik yang bermakna pada ruang kognisi siswa. Kebermaknaan suatu peristiwa, fenomena, dan proses belajar berdampak pada terisinya ruang kognisi siswa dengan memori-memori jangka panjang. Pada pembelajaran verifikasi, pengalaman partisipatif siswa terbatas pada menerima informasi dengan mendengarkan dan mencatat penjelasan guru. Pengetahuan yang didapat dari pengalaman dengan kebermaknaan yang kurang hanya meninggalkan jejak informasi pada memori jangka pendek. Hal ini menyebabkan retensi siswa pada kelas verifikasi menjadi tidak maksimal, sebab retensi menjadi maksimal ketika siswa mendeklarasikan apa yang mereka alami, identifikasi, dan analisis secara mandiri.

Hasil penelitian ini dikaji lebih lanjut dengan menampilkan sebaran pola jawaban kemampuan problem solving siswa pada salah satu soal yang dapat mencerminkan perbedaan skor rata-rata pada kedua kelas. Sebaran pola jawaban kemampuan problem solving siswa pada nomor 1 disajikan pada Tabel 4.

Tabel 4. Sebaran Pola Jawaban Soal No 1 tentang Masalah Pengasaman Lautan

\begin{tabular}{|c|c|c|c|c|c|c|}
\hline \multirow{2}{*}{ No } & \multirow{2}{*}{ Pola Jawaban } & \multirow{2}{*}{ Skor } & \multicolumn{2}{|c|}{ POGIL } & \multicolumn{2}{|c|}{ Verifikasi } \\
\hline & & & $\mathbf{N}$ & $\%$ & $\mathbf{N}$ & $\%$ \\
\hline \multirow[t]{2}{*}{1} & $\begin{array}{l}\text { Karbon dioksida yang diserap air laut akan membentuk asam } \\
\text { karbonat } \mathrm{H}_{2} \mathrm{CO}_{3} \text { dan meningkatkan keasaman air laut (adanya } \\
\left.\text { ion } \mathrm{H}^{+}\right) \text {. } \\
\mathrm{CO}_{2}(g)+\mathrm{H}_{2} \mathrm{O}(\mathrm{l}) \rightleftharpoons \mathrm{H}_{2} \mathrm{CO}_{3}(\text { aq }) \\
\mathrm{H}_{2} \mathrm{CO}_{3}(a q) \rightleftharpoons \mathrm{H}^{+}(a q)+\mathrm{HCO}_{3}^{-}(a q)\end{array}$ & \multirow[t]{2}{*}{3} & 15 & 55,5 & 9 & 32,1 \\
\hline & $\begin{array}{l}\text { Maka, air laut kekurangan karbonat }\left(\mathrm{CO}_{3}^{2-}\right) \text { sehingga hewan- } \\
\text { hewan laut bercangkang serta karang lebih mudah mati karena } \\
\text { membutuhkan banyak energi untuk membentuk cangkang. } \\
\mathrm{H}^{+}(a q)+\mathrm{CO}_{3}^{2-}(a q) \rightleftharpoons \mathrm{HCO}_{3}^{-}(a q)\end{array}$ & & 0 & 0 & 1 & 3,6 \\
\hline 2 & $\begin{array}{l}\text { Gas } \mathrm{CO}_{2} \text { masuk ke laut bersatu dengan air }\left(\mathrm{H}_{2} \mathrm{O}\right) \text { dan } \\
\text { mengganggu kestabilan ekosistem laut dan merugikan } \\
\text { organisme-organisme yang hidup di laut. } \\
\mathrm{CO}_{2}(g)+\mathrm{H}_{2} \mathrm{O}(\mathrm{l}) \rightleftharpoons \mathrm{H}_{2} \mathrm{CO}_{3}(a q)\end{array}$ & 2 & 5 & 18,5 & 7 & 25 \\
\hline 3 & $\begin{array}{l}\text { Jumlah } \mathrm{CO}_{2} \text { meningkat, lautan menyerap } \mathrm{CO}_{2}, \mathrm{pH} \text { lautan } \\
\text { menurun karena dihasilkan ion } \mathrm{H}^{+} \text {. }\end{array}$ & 2 & 7 & 25,9 & 8 & 28,6 \\
\hline
\end{tabular}




\begin{tabular}{|c|c|c|c|c|c|c|}
\hline & $\mathrm{CO}_{2}+\mathrm{H}_{2} \mathrm{O} \rightleftharpoons 2 \mathrm{H}^{+}+\mathrm{CO}_{3}^{2-}$ & & & & & \\
\hline \multirow[t]{2}{*}{4} & $\begin{array}{l}\text { Semakin banyak } \mathrm{CO}_{2} \text { yang terlarut dalam lautan, maka } \mathrm{pH} \\
\text { lautan akan menurun dan mengganggu kestabilan ekosistem } \\
\mathrm{CO}_{2}+\mathrm{H}_{2} \mathrm{O} \rightleftharpoons \mathrm{H}_{2}+\mathrm{CO}_{3}\end{array}$ & 1 & 0 & 0 & 1 & 3,6 \\
\hline & $\mathrm{H}^{+}+\mathrm{CO}^{2-} \rightleftharpoons \mathrm{HCO}^{2-}$ & & 0 & 0 & 2 & 7,1 \\
\hline
\end{tabular}

Berdasarkan koding jawaban pada Tabel 4, tampak bahwa 55,5\% siswa kelas POGIL memberikan solving terhadap problem dengan skor maksimal, jauh lebih tinggi dari persentase siswa kelas verifikasi sebanyak 32,1\%. 12 siswa kelas POGIL mendapatkan skor 2 karena tidak memberikan reaksi yang lengkap, lebih sedikit dari 15 siswa kelas verifikasi pada jawaban yang sama. 3 siswa kelas verifikasi hanya mendapat skor 1 karena memberikan reaksi yang tidak tepat, sesuatu hal yang tidak dilakukan siswa kelas POGIL. Dari sebaran jawaban tersebut, dapat disimpulkan bahwa siswa kelas POGIL memiliki kemampuan transfer yang lebih baik dalam mengaplikasikan teori-teori asam-basa menjadi rangkaian solusi permasalahan yang diberikan dibandingkan siswa kelas verifikasi. Selain itu, siswa kelas POGIL memiliki kemampuan proses yang lebih baik dalam hal menuliskan persamaan reaksi secara tepat sesuai fenomena yang diberikan dibandingkan kelas verifikasi.

Kemampuan problem solving seperti pada Tabel 4 dapat berkembang apabila terjadi koordinasi dan integrasi sejumlah kemampuan. Pengetahuan dasar terhadap konsep dan fakta, pengetahuan tentang metode heuristik, koordinasi kemampuan, dan pemantauan progress terhadap solusi masalah merupakan sejumlah kemampuan yang harus dikembangkan untuk membentuk kemampuan problem solving yang efektif (Noh et al., 2005). Pada pembelajaran verifikasi, kemampuankemampuan tersebut belum tampak, sebab transfer pengetahuan yang diikuti pemberian soal latihan tidak melatih siswa mengkoordinasi pengetahuan ke dalam permasalahan baru. Komponen kunci mengembangkan kemampuan problem solving adalah memberikan relevansi dan pemaknaan suatu topik kepada siswa. Dengan demikian, pembelajaran sains hendaknya didesain menjadi pembelajaran yang bermakna (meaningful learning) dimana siswa dapat mengaplikasikan pengetahuan yang didapat pada konteks baru (Kipnis \& Hofstein, 2008).
Siswa yang dibelajarkan menggunakan pendekatan POGIL memiliki retensi yang lebih baik daripada siswa yang dibelajarkan menggunakan pendekatan verifikasi. Retensi dapat terfasilitasi apabila siswa dilibatkan aktif dalam pembelajaran berbasis penemuan daripada melalui pembelajaran pasif yang mengutamakan transfer informasi dari ceramah dan buku teks. Pembelajaran berbasis penemuan seperti POGIL membentuk sebuah pengalaman empirik yang bermakna pada ruang kognisi siswa. Kebermaknaan suatu peristiwa, fenomena, dan proses belajar berdampak pada terisinya ruang kognisi siswa dengan memorimemori jangka panjang. Pada pembelajaran verifikasi, pengalaman partisipatif siswa terbatas pada menerima informasi dengan mendengarkan dan mencatat penjelasan guru. Pengetahuan yang didapat dari pengalaman dengan kebermaknaan yang kurang hanya meninggalkan jejak informasi pada memori jangka pendek. Hal ini menyebabkan retensi siswa pada kelas verifikasi menjadi tidak maksimal, sebab retensi menjadi maksimal ketika siswa mendeklarasikan apa yang mereka alami, identifikasi, dan analisis secara mandiri.

Inkuiri versi POGIL dapat mengakomodasi keterlaksanaan meaningful learning. Pada pembelajaran inkuiri, siswa dapat membangun pengetahuan, mengaplikasikannya untuk menyelesaikan masalah pada situasi baru, dan menghasilkan pengetahuan baru layaknya seorang peneliti. Problem solving layak diupayakan dalam pembelajaran sebab problem solving merupakan topik sentral pada konteks pendidikan modern dan mendapat perhatian khusus dari organisasi penilai pendidikan Programme for International Student Assessment (PISA) sebagai parameter kualitas pendidikan suatu negara (Greiff, 2012). Siswa perlu dibentuk menjadi pebelajar cepat (quick learners), pemikir kritis (critical thinkers), dan penyelesai masalah (problem solvers) untuk mengimbangi perkembangan zaman dan teknologi yang begitu cepat (Hanson, 2005). 
Hasil penelitian mendukung bahwa inkuiri dapat mengakomodasi problem solving pada tahap aplikasi (Eberlein et al., 2008; Hanson, 2005; Moog \& Spencer, 2008). Sebuah problem membutuhkan siswa untuk mentransfer pengetahuan baru pada konteks yang belum familiar, mensintesisnya dengan pengetahuan lain, dan menggunakannya pada cara berbeda dalam menyelesaikan permasalahan dunia nyata. Pada POGIL, problem diberikan dengan syarat masih berkaitan dekat dengan konsep yang diajarkan. POGIL dapat mengembangkan kemampuan siswa dalam menyelesaikan suatu problem (Karadan \& Hameed, 2016).

Hasil pada penelitian ini sejalan dengan sejumlah gagasan peneliti terdahulu. (Hanson, 2005) menyatakan bahwa aktivitas problem solving pada POGIL yang diberikan pada tahap aplikasi dapat memicu siswa secara sadar menggunakan konsep yang telah didapat pada tahap konstruksi konsep ke dalam situasi baru. Sejumlah peneliti juga menyatakan bahwa inkuiri memberikan banyak pengalaman untuk mengembangkan kemampuan sehingga dapat ditransfer secara spontan ketika diberikan problem yang tidak familiar (Hmelo \& Williams, 2018; Jonassen \& Hung, 2008). Sejumlah ahli juga menyatakan bahwa POGIL dapat memfasilitasi siswa dalam mengembangkan kemampuan memecahkan masalah terkait konsep berkaitan (Karadan \& Hameed, 2016; Zawadzki, 2010). Problem solving lebih tepat dilatihkan pada pembelajaran yang mengedepankan konstruksi pengetahuan. Dalam hal ini, POGIL sangat memfasilitasi adanya konstruksi pengetahuan tersebut, sehingga kemampuan problem solving yang diharapkan menjadi maksimal.

Hasil pada penelitian ini juga mendukung hasil penelitian terdahulu. Aktivitas inkuiri pada siswa SMA diberikan bantuan scaffolding berupa pertanyaan-pertanyaan pembimbing maupun model-model ilmiah yang cukup, maka akan menghasilkan aktivitas problem solving yang lebih baik daripada kelas tanpa scaffolding yang mencukupi (Irwanto et al., 2018; Raes et al., 2012). Sejumlah penelitian juga melaporkan sekaligus menyarankan bahwa problem solving layak dipromosikan dalam pembelajaran sains baik sebagai hasil belajar maupun sebagai teknik pedagogik (Parr \& Edwards, 2004; Peelle, 2005).

Pembelajaran POGIL juga mulai banyak digunakan pada aktivitas belajar dan penelitian di Indonesia. Penelitian pada siswa SMA di Kabupaten Purworejo menunjukkan bahwa penggunaan pembelajaran berbasis penemuan menghasilkan kemampuan pemecahan masalah kimia yang lebih baik sebesar $81 \%$ pada kelas eksperimen dan $41 \%$ pada kelas kontrol. Pembelajaran berbasis penemuan atau inkuiri menghasilkan keterlibatan siswa dalam mengkonstruksi konsep secara mandiri, terciptanya dinamika kelompok dalam proses pemecahan masalah, mengaktifkan pemikiran kritis siswa, dan meningkatkan kemampuan siswa dalam mengaplikasikan pengetahuan pada permasalahan dunia nyata (Sulistyowati et al., 2012).

POGIL juga digunakan untuk pembelajaran fisika dan terbukti dapat meningkatkan kemampuan berpikir kritis siswa (Ningsih \& Bambang, 2012). Penerapan POGIL pada bokok bahasan kalor menghasilkan $75 \%$ siswa dapat melakukan kemampuan berpikir kritis pada kategori sangat kritis. Ditemukan pula bahwa POGIL berpotensi dapat meningkatkan kemampuan berpikir analitis, memecahkan masalah, melaporkan, metakognisi, dan rasa tanggung jawab individu sebagai siswa. Pengembangan modul elektronik menggunakan pendekatan POGIL untuk siswa SMK kelas X pada topik kimia reaksi reduksi-oksidasi menghasilkan tingkat penerimaan cukup besar dan layak digunakan dalam pembelajaran pada siswa secara mandiri (Cahayningrum et al., 2017). Modul dikembangkan dengan mengintegrasikan pengetahuan ke dalam permasalahan nyata sehingga dapat melatihkan kemampuan berpikir siswa.

Sejumlah penelitian diatas mendukung kajian literatur bahwa POGIL dapat meningkatkan keterampilan proses, kemampuan berpikir, keterampilan menyelesaikan masalah (problem solving), dan meningkatkan kemampuan kognitif siswa (Zamista \& Kaniawati, 2016). Pembelajaran POGIL cocok digunakan untuk rumpun eksakta seperti fisika dan kimia sebab rumpun tersebut merupakan bagian dari proses sains dan terdapat metode ilmiah. Model pembelajaran 
POGIL merupakan model pembelajaran yang menekankan pada proses kontruktivisme yang memfasilitasi siswa untuk melatihkan keterampilan proses, membangun kemampuan kognitifnya sendiri, dan menumbuhkan sikap positif.

\section{Temuan Tambahan}

Temuan tambahan yang dapat dikaji pada penelitian ini adalah adanya aktivitas komponen metakognisi yaitu pengetahuan metakognitif pada pembelajaran POGIL topik asam-basa. Temuan ini dapat dikaji dari jawaban siswa yang disajikan pada Tabel 4 . Siswa yang diajarkan menggunakan POGIL memberikan jawaban problem solving yang lebih lengkap dan sistematis dibandingkan kelas verifikasi. Sajian jawaban yang lengkap dan sistematis menunjukkan adanya aktivitas metakognisi yang lebih baik. Metakognisi adalah pengetahuan tentang proses dan produk kognitif seseorang, thinking about one's own thinking (Flavell, 1979). Metakognisi juga berkaitan dengan regulasi, monitor, dan orkestrasi objek kognitif secara konsekuen selama proses belajar dan dalam penyelesaian suatu tugas sehingga objek kognitif tersebut dapat disajikan dengan lebih baik dalam bentuk jawaban problem solving.

Aktivitas inkuiri dapat memicu siswa melibatkan pengetahuan metakognitif (Kipnis \& Hofstein, 2008). Siswa dalam aktivitas inkuiri terbimbing mengkonstruk gagasan baru dari berdasar pengetahuan dan pengalaman sebelumnya, mendapat pengetahuan sesuai dengan aktivitas mental diri, saling berinteraksi, mengetahui tentang strategi belajar yang efektif, menentukan kebutuhan belajar yang tepat, memahami tugas, memantau kemajuan tugas tersebut, serta melakukan refleksi dan penilaian terhadap sejumlah strategi (Karadan \& Hameed, 2016). Jika inkuiri disusun dengan benar, maka dapat menghasilkan tingkat metakognisi yang diinginkan.

Siswa yang dibelajarkan menggunakan pendekatan POGIL memperoleh kepemilikan belajar (take ownership of learning) yang lebih melekat dibandingkan siswa yang dibelajarkan menggunakan pendekatan verifikasi. Tiap tahap pembelajaran POGIL memicu munculnya serangkaian aktivitas kognitif dalam dinamika pikiran siswa. Aktivitas kognitif tersebut tertaut dari satu tahap POGIL ke tahap lain yang harus dikelola secara mandiri oleh kognisi siswa menjadi sebuah proses belajar yang berkesinambungan. Tata kelola aktivitas kognitif yang dikendalikan oleh kognisi diri secara aktif merupakan indikator adanya aktivitas metakognitif terhadap adanya kesadaran, kepemilikan, dan tanggung jawab siswa terhadap pembelajaran POGIL.

Hal ini sejalan dengan peneliti yang menyatakan bahwa pada POGIL, metakognisi dapat tumbuh karena adanya kesadaran siswa akan proses belajar yang dilakukan (selfmanagement) (Hanson, 2005; Karadan \& Hameed, 2016; Moog \& Spencer, 2008). Pada pembelajaran verifikasi, kendali belajar didominasi oleh ceramah guru dan kepemilikian belajar tidak secara otentik tersalurkan ke dalam ruang kognisi siswa. Hilangnya aktivitas kognitif yang seharusnya dikendalikan oleh kognisi siswa secara mandiri kini berpindah ke tangan guru sebagai pemangku segala kebijakan kelas. Kendali kognisi siswa yang terisolir oleh dominasi guru mengakibatkan aktivitas metakognitif sulit berkembang pada pembelajaran verifikasi.

Temuan tambahan ini sejalan dengan sejumlah penelitian bahwa POGIL dapat mengembangkan pengetahuan metakognitif. POGIL menciptakan kesadaran dan pemahaman tentang proses berpikir dan penggunaan sejumlah strategi selama proses pembelajaran (Karadan \& Hameed, 2016). POGIL menciptakan suatu aktivitas metakognitif bahwa mereka sedang mengatur dan memantau proses belajarnya (self-management dan selfregulation), mengorientasi diri pada performa (self-assessment), dan melakukan refleksi terhadap apa yang telah mereka pelajari dan belum mereka pahami (reflection on learning) (Hanson et al., 2006). Metakognisi menghasilkan atmosfer berpikir secara kritis tentang keterlibatan siswa pada proses belajar. Siswa perlu mengenali kapan memahami konsep dan mengaplikasannya untuk menyelesaikan masalah baru. Siswa dipicu bertanya pada diri (self-questioning) seperti apakah saya mempunyai semua informasi, apakah saya telah menggunakan strategi yang 
tepat, dan apakah ada alternatif strategi yang lebih baik.

Temuan lain yang dapat dieksplorasi lebih lanjut adalah adanya kaitan erat kognisi, metakognisi, dan problem solving yang sebelumnya telah dinyatakan (Zohar \& Dori, 2012). Metakognisi merupakan terminologi untuk kognisi pada level yang lebih tinggi, higher-order cognition about cognition. Kognisi dibutuhkan untuk eksekusi dari suatu tugas pada tingkatan objek, sedangkan metakognisi merupakan diferensiasi dari kognisi yang merepresentasikan fungsi eksekutif dalam proses organisasi aktivitas kognitif. Pengetahuan metakognitif seseorang terhadap sebuah kompetensi akademik tidak dapat dilihat tanpa adanya kognisi berkaitan konsep, teori, dan konten keilmuan terkait. Begitu pula dengan regulasi metakognitif, seseorang tidak dapat melakukan planning tanpa melakukan aktivitas kognitif seperti menyusun langkah problem solving dan mengurutkan langkahlangkah tersebut.

\section{Keterbatasan Potensial}

POGIL terbukti efektif dapat memberikan hasil yang signifikan terhadap kemampuan pemecahan masalah siswa. Namun, sejumlah kendala penelitian yang ditemui adalah 1) banyaknya kegiatan ekstrakurikuler dan OSIS membuat pembelajaran sedikit terhambat oleh banyaknya siswa yang absen mengingat pemilihan sampel adalah kelas $\mathrm{Xl}$; 2) pembelajaran berbasis inkuiri seperti POGIL membutuhkan waktu yang lebih lama daripada pembelajaran biasa; dan 3) pembelajaran POGIL menuntut guru mengkontrol seluruh kemajuan belajar siswa sehingga membutuhkan energi yang lebih besar dari guru. Kendala-kendala tersebut dapat menjadi pertimbangan oleh penelitian selanjutnya agara menghasilkan hasil yang lebih akurat dan berkualitas.

Pada penelitian ini juga terdapat keterbatasan-keterbatasan potensial yang diharapkan membuka peluang bagi peneliti lainnya untuk melakukan penelitian sejenis diantaranya adalah: (1) topik yang diteliti hanya terbatas pada asam-basa, masih terbuka banyak peluang untuk penelitian aktivitas problem solving pada topik lain mengingat topik-topik kimia sebagian besar bersifat kontekstual. Topik-topik kimia yang disarankan adalah kesetimbangan, laju reaksi, sifat koligatif, dan termokimia; (2) subjek penelitian hanya dipilih pada satu sekolah di Kota Malang yang notabene kota besar dengan karakteristik siswa yang modern. Perlu dilakukan penelitian kemampuan problem solving siswa di kawasan rural/pedesaan untuk membandingkan pengaruh karakteristik siswa sehingga berpotensi menghasilkan temuan yang menarik; dan (3) kemampuan problem solving merupakan kemampuan skill yang kompleks, perlu dilakukan penelitian untuk meneliti dari segi sikap dan kemampuan proses selama langkah-langkah menyelesaikan problem, sehingga kemampuan problem solving tidak hanya dilihat dari jawaban akhir siswa.

\section{PENUTUP}

\section{Simpulan}

Kesimpulan dalam penelitian ini adalah terdapat perbedaan kemampuan problem solving siswa pada topik asam-basa yang dibelajarkan menggunakan POGIL dan verifikasi. Siswa yang dibelajarkan menggunakan POGIL memiliki kemampuan problem solving yang lebih tinggi daripada siswa yang dibelajarkan menggunakan verifikasi. Kemampuan problem solving yang lebih tinggi dibuktikan dengan sebaran pola jawaban benar lebih banyak pada kelas POGIL dibandingkan verifikasi. Pada penelitian ini juga ditemukan adanya aktivitas komponen metakognisi yaitu pengetahuan metakognitif pada pembelajaran POGIL topik asam-basa yang dapat dilihat dari perbedaan sajian jawaban siswa pada problem yang diberikan.

\section{Rekomendasi}

Pembelajaran topik asam-basa sewajarnya dilakukan menggunakan pendekatan yang memicu stimulasi intelektual siswa secara aktif dan dengan metodologi ilmiah yang sistematis, dalam hal ini inkuiri versi POGIL lebih disarankan. Dalam hal ini, problem solving layak dipromosikan dalam pembelajaran agar siswa terlatih dalam mentransfer perolehan konsep ke dalam situasi baru. Pembelajaran pada topik Asam-Basa juga disarankan melibatkan tiga level representasi makroskopik, 
submikroskopik, dan simbolik, sebab banyak siswa belum terlatihkan mengerjakan soal dengan mengaitkan ketiga representasi tersebut. Keterlibatan tiga level representasi makroskopik, submikroskopik, dan simbolik dapat memicu berkembangnya kemampuan problem solving siswa. Tiga level representasi tersebut dapat diintegrasikan ke dalam tahapan-tahapan POGIL. 


\section{DAFTAR PUSTAKA}

Abd-El-Khalick, F., Boujaoude, S., Duschl, R., Lederman, N. G., Mamlok-Naaman, R., Hofstein, A., Niaz, M., Treagust, D., \& Tuan, H. L. (2004). Inquiry in science education: International perspectives. Science Education, 88(3), 397-419. https://doi.org/10.1002/sce.10118

Bilgin, I. (2006). The Effects of Pair Problem Solving Technique Incorporating Polya's Problem Solving Strategy on Undergraduate Students' Performance in Chemistry. In Online Submission (Vol. 7, Issue 2, pp. 101106).

Broman, K., \& Parchmann, I. (2014). Students' application of chemical concepts when solving chemistry problems in different contexts. Chemistry Education Research and Practice, 15(4), 516-529. https://doi.org/10.1039/c4rp00051j

Cahayningrum, R. D., Nurjayadi, M., \& Rahman, A. (2017). Pengembangan E-Module Kimia Berbasis Pogil (Process Oriented Guided Inquiry Learning) Pada Materi Reaksi Reduksi-Oksidasi Sebagai Sumber Belajar Siswa. JRPK: Jurnal Riset Pendidikan Kimia, 7(1), 59-65. https://doi.org/10.21009/jrpk.071.07

Çalik, M., \& Ayas, A. (2005). A cross-age study on the understanding of chemical solutions and their components. International Education Journal, 6(1), 30-41.

De Vos, W., \& Pilot, A. (2001). Acids and bases in layers: The stratal structure of an ancient topic. Journal of Chemical Education, 78(4), 494-499. https://doi.org/10.1021/ed078p494

Dudley Herron, J., \& Nurrenbern, S. C. (1999). Chemical Education Research: Improving Chemistry Learning. Journal of Chemical Education, 76(10), 1354-1361. https://doi.org/10.1021/ed076p1353

Eberlein, T., Kampmeier, J., Minderhout, V., Moog, R. S., Platt, T., Varma-Nelson, P., \& White, H. B. (2008). Pedagogies of engagement in science: A comparison of PBL, POGIL, and PLTL. Biochemistry and Molecular Biology Education, 36(4), 262-273. https://doi.org/10.1002/bmb.20204

Flavell, J. H. (1979). Metacognition and Cognitive Monitoring A New Area of Cognitive - Developmental Inquiry. American Psychological Association, 34(10), 906-911.

Furió-Más, C., Calatayud, M. L., \& Bárcenas, S. L. (2007). Surveying students' conceptual and procedural knowledge of acid-base behavior of substances. Journal of Chemical Education, 84(10), 1717-1724. https://doi.org/10.1021/ed084p1717

Gabel, D. (1999). Improving Teaching and Learning through Chemistry Education Research: A Look to the Future. Journal of Chemical Education, 76(2-4), 548-554. https://doi.org/10.1021/ed076p548

Greiff, S. (2012). From interactive to collaborative problem solving: Current issues in the Programme for International Student Assessment. From Interactive to Collaborative Problem Solving: Current Issues in the Programme for International Student Assessment, 19(2), 111-121.

Hanson, D. M. (2005). Designing Process-Oriented Guided-Inquiry Activities. In Faculty Guidebook - A Comprehensive Tool for Improving Faculty Performance (pp. 1-6). Stony Brook University.

Hanson, D. M., Bunce, D., Creegan, F., Moog, R., Padwa, L., Spencer, J., Straumanis, A., \& Wolfskill, T. (2006). Instructor's Guide to Guided-Inquiry Learning by With Contributions from other POGIL project personnel : Instructor's Guide to Process-Oriented Guided-Inquiry Learning.

Hmelo, C. E., \& Williams, S. M. (2018). Learning through Problem Solving. The Journal of the Learning Sciences, 7(3-4), 265-270. https://doi.org/10.4324/9780203764411

Irwanto, Saputro, A. D., Rohaeti, E., \& Prodjosantoso, A. K. (2018). Promoting critical thinking and Problem Solving Skills of Preservice Elementary Teachers through Process-Oriented Guided-Inquiry Learning (POGIL). International Journal of Instruction, 11(4), 777-794.

https://doi.org/10.12973/iji.2018.11449a 
Jonassen, D. H., \& Hung, W. (2008). Interdisciplinary Journal of Problem-Based Learning All Problems are Not Equal: Implications for Problem-Based Learning. Interdisciplinary Journal of Problem-Based Learning, 2(2), 10-13. https://doi.org/10.7771/1541-5015.1080

Karadan, M., \& Hameed, A. D. (2016). Exploring the Features of Metacognition and Achievement Goals in Process Oriented Guided Inquiry Learning Instruction ( POGIL ). International Journal of Education and Psychological Research (IJEPR), 5(3), 39-43.

Kipnis, M., \& Hofstein, A. (2008). The inquiry laboratory as a source for development of metacognitive skills. International Journal of Science and Mathematics Education, 6(3), 601-627. https://doi.org/10.1007/s10763-007-9066-y

Moog, R. S., \& Spencer, J. N. (2008). POGIL: An overview. ACS Symposium Series, 994, 1-13. https://doi.org/10.1021/bk-2008-0994.ch001

Moshman, D. (2018). Metacognitive Theories Revisited. Educational Psychology Review, 30(2), 599-606. https://doi.org/10.1007/s10648-017-9413-7

Nada, E. I., Mursiti, S., \& Susilaningsih, E. (2018). Journal of Innovative Science Education Analysis Concepts Redox Using Multiple Representation Based Test Instrument with Computer Based Test ( CBT ) Model model , define , design , develop and disseminate. The purpose of instrument can be used for the an. Journal of Innovative Science Education, 7(1), 101-106.

Nakhleh, M. B. (1994). Students' models of matter in the context of acid-base chemistry. Journal of Chemical Education, 71(6), 495-499. https://doi.org/10.1021/ed071p495

Ningsih, S. M., \& Bambang, S. (2012). Implementasi Model Pembelajaran Process Oriented Guided Inquiry Learning (Pogil) Untuk Meningkatkan Kemampuan Berpikir Kritis Siswa. UPEJ (Unnes Physics Education Journal), 1(2). https://doi.org/10.15294/upej.vli2.1364

Noh, T., Jeon, K., \& Huffman, D. (2005). The Effects of Thinking Aloud Pair Problem Solving on High School Students' Chemistry Problem-Solving Performance and Verbal Interactions. Journal of Chemical Education, 82(10), 1558-1564. https://doi.org/10.1021/ed082p1558

OECD. (2019). PISA 2018 insights and interpretations. In OECD Publishing. https://www.oecd.org/pisa/PISA 2018 Insights and Interpretations FINAL PDF.pdf

Orgill, M. K., \& Sutherland, A. (2008). Undergraduate chemistry students' perceptions of and misconceptions about buffers and buffer problems. Chemistry Education Research and Practice, 9(2), 131-143. https://doi.org/10.1039/b806229n

Parr, B., \& Edwards, M. C. (2004). Inquiry-Based Instruction In Secondary Agricultural Education: ProblemSolving - An Old Friend Revisited. Journal of Agricultural Education, 45(4), 106-117. https://doi.org/10.5032/jae.2004.04106

Pavelich, M. J., \& Abraham, M. R. (1979). An Inquiry Format Laboratory Program for. JJournal of Chemical Education, 56(2), 100-103.

Peelle, H. E. (2005). Appreciative Inquiry and Creative Problem Solving (Issue March). University of Phoenix.

Pinarbasi, T. (2007). Turkish undergraduate students' misconceptions on acids and bases. Journal of Baltic Science Education, 6(1), 23-34.

Raes, A., Schellens, T., De Wever, B., \& Vanderhoven, E. (2012). Scaffolding information problem solving in web-based collaborative inquiry learning. Computers and Education, 59(1), 82-94. https://doi.org/10.1016/j.compedu.2011.11.010

Schraw, G., Crippen, K. J., \& Hartley, K. (2006). Promoting self-regulation in science education: Metacognition as part of a broader perspective on learning. Research in Science Education, 36(1-2), 111-139. https://doi.org/10.1007/s11165-005-3917-8

Sheppard, K. (2006). High school students' understanding of titrations and related acid-base phenomena. 
Chemistry Education Research and Practice, 7(1), 32-45. https://doi.org/10.1039/B5RP90014]

Sulistyowati, N., Widodo, A. T., \& Sumarni, W. (2012). Efektivitas Model Pembelajaran Guided Discovery Learning Terhadap Kemampuan Pemecahan Masalah Kimia. Chemistry in Education, 1(2), 49-55.

Thomas, G. P., \& Anderson, D. (2014). Changing the metacognitive orientation of a classroom environment to enhance students' metacognition regarding chemistry learning. Learning Environments Research, 17(1), 139-155. https://doi.org/10.1007/s10984-013-9153-7

Tümay, H. (2016). Emergence, Learning Difficulties, and Misconceptions in Chemistry Undergraduate Students' Conceptualizations of Acid Strength. Science and Education, 25(1-2), 21-46. https://doi.org/10.1007/s11191-015-9799-x

Wood, C. (2006). The development of creative problem solving in chemistry. Chemistry Education Research and Practice, 7(2), 96-113. https://doi.org/10.1039/B6RP90003H

Woods, D. R. (1987). How Might I Teach Problem Solving? In New Directions for Teaching and Learning (Issue 30, pp. 55-71). Jossey-Bass.

Yuliastini, I. B., Rahayu, S., Fajaroh, F., \& Mansour, N. (2018). Effectiveness of pogil with ssi context on vocational high school students' chemistry learning motivation. Jurnal Pendidikan IPA Indonesia, 7(1), 8595. https://doi.org/10.15294/jpii.v7i1.9928

Zamista, A. A., \& Kaniawati, I. (2016). Pengaruh Model Pembelajaran Process Oriented Guided Inquiry Learning Terhadap Keterampilan Proses Sains Dan Kemampuan Kognitif Siswa Pada Mata Pelajaran Fisika. Edusains, 7(2), 191-201. https://doi.org/10.15408/es.v7i2.1815

Zawadzki, R. (2010). Is process-oriented guided-inquiry learning (POGIL) suitable as a teaching method in Thailand's higher education? Asian Journal on Education and Learning, 1(2), 66-74. www.ajel.info

Zohar, A., \& Dori, Y. (2012). Metacognition in science education: Trends in current research. Trends in Current Research, 40, 251-271. https://doi.org/10.1007/978-94-007-2132-6 